\title{
An empirical study on effects of downsizing on private firms
}

\author{
Mansour Ezati Jivan
}

MA in Business Administration; Managing Director of Iranian Management System Company (Iran SAMA), Iran

\begin{tabular}{l}
\hline A R T I C L E I N F O \\
\hline Article history: \\
Received December 20, 2011 \\
Received in Revised form \\
March, 25, 2012 \\
Accepted 20 April 2012 \\
Available online \\
April 27 2012 \\
\hline Keywords: \\
Downsizing \\
Productivity \\
Cost reduction \\
Information Technology
\end{tabular}
A B S T R A C T

\begin{abstract}
Many organizations may reduce on the number of their employees in an attempt to reduce their operating cost and increase efficiency of their units. The workers who normally leave the firms are not believed to be productive for other organizations. On the other hands, there are some side effects on the remaining workers since they may feel they are losing their job securities. As a result, they may have mistrust towards their managers and start working less to pretend that downsizing yields negative consequences. In this paper, we survey on some information technology based organizations where such downsizing incidents have already occurred and analyze whether downsizing could reach its mission, properly or not. The results of this survey indicate that although downsizing can reduce the operating cost, it has some negative impacts on workers as well.
\end{abstract}

\section{Introduction}

During the past few decades, different factors such as globalization, economic growth, market fluctuation, mergers among different firms and takeover incidents have improved productivity of organizations. One of the common issues among productivity improvement techniques is to use downsizing by reducing human resources. Downsizing is a new concept and many organizations have not implemented it, successfully. According to Chao (2010), organizations may normally look for special objectives through downsizing and the first step in downsizing is to setup an appropriate strategy. Therefore, we need to specify macro objectives and justify the reasons for downsizing. When all objectives become clear through organization before downsizing happens, workers have better perception on the reasons of downsizing. On the other side, organizations are able to receive appropriate feedbacks from the workers and could meet organizations' objectives, more successfully. There are normally three strategies for downsizing and the focus of this survey is on reducing permanent employees of organizations.

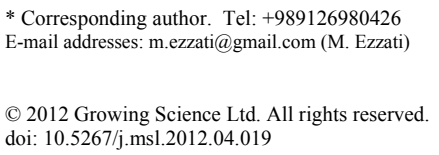


There are literally many studies accomplished to study the effects of downsizing on workers' emotional feeling as well as their healthcare. Bohle et al. (2001) reported that downsizing could impact workers' healthcare based on a research work. Dragano et al. (2005) in similar work reported that downsizing could increase stress among the remaining employees and destabilizes organization, substantially. Adam and Flatau (2006) investigated the relationship between job security and workers' healthcare among some workers who were residence of Australia and reported meaningful relationship between these two items.

In this paper, we perform an empirical study to measure the effects of downsizing in an organization in Iran and provide some insight to reduce the negative impacts of downsizing.

\section{Downsizing}

Downsizing is a set of activities used to improve the efficiency and performance of an organization and it influences on human resources, costs and processes (Anwar, 2009). This term was first used for reducing the size of cars in United States (Wood, 1995). The most important part of downsizing is associated with the logic of the work, which means organizations must have a legitimate reason for reducing the size of an organization. This includes cost reduction, strategy, survivor's syndrome and fairness.

\subsection{Reduce the cost of rationality}

The logic that many organizations execute downsizing is established on cost reduction, which is achieved by reducing the number unnecessary jobs (Chao, 2010). Of course, cost reduction happens only when other components of productivity in organizations remain the same (Kar \& Beladi, 2004). The recent studies have demonstrated that downsizing could impact other factors and cost reduction may not happen all the time. For instance, workers' motivation and productivity and organization capability on absorbing new projects may be reduced (Chakrabarti, 2009). On the other hand, there are not many evidences to believe that downsizing could definitely end up with cost reduction.

\subsection{Downsizing strategies}

There are normally three strategies associated with downsizing, which are as follows,

\subsubsection{Workforce reduction strategy}

In this strategy, workers are encouraged to use early retirement plans or other techniques such as layoff, organization leave, etc. are used to reduce the number of people who work for organization.

\subsubsection{Job redesign strategy}

In this category, there are some changes on unnecessary activities while other activities are merged.

\subsubsection{Systematic strategy}

This strategy impacts on culture and values and downsizing is a method for survival of organization, which is used as a continuous process and not just as a one-time event.

\subsection{Survivor's syndrome and fairness}

As we explained earlier, when downsizing happens there are some consequences on the remaining human resources. When a significant number of workers are asked to leave, other workers may feel worry about their own job security and they may think that sooner or later they will be also asked to leave. They may feel guilty because they think the people who lost their jobs were better. Therefore, there may be some consequences on the performance of organization for a while (Matikainen, 2008). Ichino (2005) in a survey explained that while managers of a particular organization believed they 
could reach $79 \%$ of their objectives by downsizing, only $45 \%$ of the actual downsizing objectives were achieved.

\subsection{Having fairness in downsizing organization}

The other important factor for the success of downsizing is the feeling the remaining workers have when downsizing occurs. According to Walde et al. (2007), all people must think that downsizing would be an unavoidable event of organization and the consequences influence all parts of an organization (ACTU, 2002). For a successful implementation of downsizing, details of operations must be explained to all workers and they may be informed about the positive consequences of the action.

\subsection{Workers participation in downsizing}

Although, it is proven that when workers are asked to share their thoughts on downsizing (Layton, 1987) but Cascio (2004) believed that many organization are not able to use an appropriate method for sharing other people's idea and all workers feel disappointed about their future. Therefore, it is a good idea to share the downsizing plan among all workers (Kivimäki et al., 2000).

\section{The proposed study}

In this paper, we survey on 10 firms, which were active on information technology (IT) and focus on one of them. Their duties included selling software and hardware, training courses, consulting, etc. in Iran. In this country, government tried to pay special attention on IT based activities in year 2006 and these firms have increased their workforce in six years, significantly. Fig 2 shows the trend of workforce changes during these years. As we can observe from Fig. 1, the number of workers for these ten firms was 60 in 2006, it was increased to 600 workers in 2009 and during the last two years of study, it was reduced to 120 people by the implementation of downsizing.



Fig. 1. Workforce change in 10 IT firms of the proposed study

The proposed study of this paper performs a survey by interviewing workers on how downsizing influenced the firms. In our study, we interviewed managing director, one of the members of the board of directors, financial, administration, business administration, contract affairs, production planning, sales, research and development managers. The first set of questions was associated with the objectives of downsizing and the people who participated in our survey were asked related questions such as whether they were happy about the performance of their organization, how they could improve the performance of their organization and what was their role on increasing the productivity of an organization. Table 1 summarizes the results of our survey on these people. 


\section{Table 1}

Timetable for downsizing

Question Results

1 Management team is not satisfied on Most managers were not satisfied about the performance of the firm mainly the performance of organization.

for the following reasons,

-High operating and overhead expenditures

-sluggish trends on operations

-Lack of a good performance measurement method

2 Management suggestion on how to -Making change on some people whose performances were not good, improve performance

-Hiring experienced managers,

-Making reduction on unnecessary costs such as unimportant trips, employee reduction and reducing the number of unnecessary fixed assets.

3 How decisions are made

4 Reasons for managers for Any suggestions from management team are rarely accepted. downsizing

5 Prioritizing cost reduction and Reducing the number of unnecessary employment downsizing

Based on the results of Table 1, we can conclude that performance of the firm was not good and the focus was more on financial performance measurement. Generally, there is no common decision made by management team separately and other workers are not shared in the process of decision making procedures. Therefore, management team has recognized only one way on reducing the costs of the firm by reducing the workforces, getting rid of unnecessary buildings and fixed assets and removing unnecessary expenditures.

We have decided to ask the managers introduced earlier some important questions about the downsizing and there were varieties of questions. The first question was whether the remaining staff's average salary was taken into account after job reduction. The second question was associated with the number of future projects after downsizing. The next question was about the changes on operating cost and overheads after downsizing was accomplished. They were also asked whether short-term objectives were reached after downsizing was performed. The other question was on whether fired people expressed their envious attitudes towards people inside the organization. One other important question was on whether people have enough trust before and after privatization accomplished. Another question was whether rumors on privatization were natural.

The people who participated in our interview were also asked on whether the remaining staffs damaged organization after privatization happened, whether the remaining workers worked less and finally whether employees pretended to work more in an attempt to show that downsizing was not a good decision.

\section{Results}

In this section, we present details of our survey on different questions we asked the people who took part in our interview. Table 2 shows details of our investigation.

\section{Table 2}

The results of the interview

\begin{tabular}{llll}
\hline Question & Expectation & Actual results \\
\hline 1 & $\begin{array}{l}\text { Employee } \\
\text { reduction }\end{array}$ & $\begin{array}{l}\text { All managers believed the costs needed to } \\
\text { be reduced but they did not agree on the } \\
\text { rate of deduction. }\end{array}$ & $\begin{array}{l}\text { All managers believed the costs were reduced } \\
\text { but the rate of deduction was unclear. }\end{array}$ \\
2 & $\begin{array}{l}\text { Expected revenue } \\
\text { All managers believed revenue will be } \\
\text { increased. }\end{array}$ & On the contrary, the revenue was reduced. \\
3 & $\begin{array}{l}\text { Operating and overhear } \\
\text { cost reduction }\end{array}$ & $\begin{array}{l}\text { All managers believed the costs would be } \\
\text { reduced after downsizing accomplished. } \\
\text { Short term objectives }\end{array}$ & $\begin{array}{l}\text { All managers believed the costs were reduced } \\
\text { but the rate could not be determined. } \\
\text { 20\% disagreed. }\end{array}$ \\
\hline
\end{tabular}


Based on the results of Table 2, we can conclude that cost reduction was the only objective, which could be completely achieved from downsizing of the firm. However, even this objective was not measureable since there was not any target for cost reduction. The other part of our survey was associated with the outcome of downsizing among workers. Table 3 shows details of our survey.

\section{Table 3}

The results of the interview on workers' attitude towards management and inside organization

\begin{tabular}{llll}
\hline \multicolumn{2}{l}{ Question } & Expectation & Actual results \\
\hline 1 & Envious attitudes & $\begin{array}{l}\text { None of the people who participated } \\
\text { in interview had ever thought about it. }\end{array}$ & $\begin{array}{l}\text { All managers believed this issue was } \\
\text { increased among workers. }\end{array}$ \\
2 & Trust to management & $\begin{array}{l}\text { None of the people who participated } \\
\text { in interview had ever thought about it. }\end{array}$ & $\begin{array}{l}\text { None of the people who participated } \\
\text { in interview had ever thought about it. }\end{array}$ \\
\hline
\end{tabular}

As we can observe, management mostly agreed that downsizing could harm people's feeling and it can increase bad rumors and reduces trust to management team. The next part of the questions is associated with personality of the reaming employees. Table 4 shows details of our survey.

\section{Table 4}

The results of the interview on personal characteristics of the employees after downsizing

\begin{tabular}{|c|c|c|c|c|}
\hline & Question & & Expectation & Actual results \\
\hline 1 & Vandalizing & & $\begin{array}{l}\text { None of the people who participated } \\
\text { in interview had ever thought about it. }\end{array}$ & $\begin{array}{l}73 \% \text { believed vandalizing has increased, } \\
20 \% \text { has no information and the } \\
\text { remaining } 7 \% \text { did not make any } \\
\text { comment. }\end{array}$ \\
\hline 2 & $\begin{array}{l}\text { Shortcoming } \\
\text { duties }\end{array}$ & of & $\begin{array}{l}\text { None of the people who participated } \\
\text { in interview had ever thought about it. }\end{array}$ & $\begin{array}{l}86 \% \text { believed workers did not work } \\
\text { properly after downsizing happened. }\end{array}$ \\
\hline 3 & $\begin{array}{l}\text { Pretending } \\
\text { effectiveness }\end{array}$ & on & $\begin{array}{l}\text { None of the people who participated } \\
\text { in interview had ever thought about it. }\end{array}$ & $86 \%$ believed this was increased. \\
\hline
\end{tabular}

One important observation is that none of the people who took part in our survey had any idea about most of the questions. The other observation is that management team mostly believed that all employees' personal characteristics and their attitudes towards management team were influenced badly. Over $80 \%$ of the remaining employees were worried about their future jobs. Therefore, it was necessary to explain some of the advantages of downsizing to reduce the negative effects as much as possible. In this survey, $81 \%$ of the surveyed people believed they were not informed about downsizing and they only realized when they were asked to execute downsizing. They also believed they were told on how they chose the people for layoff and what were the criteria. In fact, had they been informed about the details of the downsizing objectives, they could have cooperated more with management team.

One of the objectives of downsizing is to reach fairness in downsizing organization. According to our survey, nearly $85 \%$ of the surveyed people believed cost reduction was necessary for organization but they all disagreed on achieving this goal through downsizing. Nearly, $90 \%$ of the people who took part in this survey believed that there were no legitimate criteria for employee reduction. About $81 \%$ of the people who participated in our survey claimed management must reduce their own payments instead of getting rid of some employees.

The other important issue is to see whether there was any plan inside the firm for employees after downsizing was accomplished. The results of our survey indicated that management did not plan ahead of time to help the remaining people cope with current circumstances. There were no training programs and no one was motivated either financially or non-financially. 
The other necessary action is to help the people who lost their jobs during downsizing procedure. There are many cases where people are encouraged to work for other firms by management but our survey indicated that management did not provide any assistance for them.

\section{Conclusion}

Downsizing is one of the most relevant techniques on increasing efficiency of a particular firm. However, downsizing could have both positive and negative consequences in organizations and in some cases; the bad consequences of mass human resource reduction could face a firm with the shortage of the necessary intangible assets. In this paper, we have presented an empirical study on the effects of downsizing on an Iranian IT based company. The results of our survey indicated that although downsizing could virtually reduce the unnecessary costs significantly but it caused many unwelcome consequences such as significant reduction on trust between employee and management, fear of unexpected layoff, etc. The paper concludes that downsizing could have had less negative consequences, had management team informed all managers and employees about the objectives, very clearly.

\section{References}

ACTU. (2002). Stop stress at work: A guide for workers, Melbourne. Australian Council of Trade Unions OHS Unit.

Adam, M., \& Flatau, P. (2006). Job insecurity and mental health outcomes: An analysis using waves 1 and 2 of HILDA. Economic and Labour Relations Review, 17, 143-170.

Anwar, S. (2009). Wage inequality, welfare and downsizing. Economics Letters, 103, 75-77.

Beladi, H., \& Chi-Chur, C. (2010).Downsizing, wage inequality and welfare in a developing economy. Research in Economics 64 .224-228

Bohle, P., Quinlan, M., \& Mayhew, C. (2001). The health effects of job insecurity: An evaluation of the evidence. Economic and Labour Relations Review, 12, 32-60.

Cascio, W. (2004). Downsizing: What do we know? What have we learned? Academy of Management Executive, 7, 95-104.

Chakrabarti, A. (2009). Internal adjustment costs in capital-intensive and labor-intensive industries. Economics Letters, 102, 76-77.

Dragano, N., Verde, P., \& Siegrist, J. (2005). Organisational downsizing and work stress: Testing synergistic health effects in employed men and women. Journal of Epidemiology and Community Health, 59, 694-699.

Kar, S., \& Beladi, H., (2004). Skill formation and international migration: welfare perspective of developing countries. Japan and the World Economy, 16, 35-54.

Kivimäki, M., Vahtera, J., Pentti, J., \& Ferrie, J. E. (2000). Factors underlying the effectof organisational downsizing on health of employees: longitudinal cohort study. British Medical Journal, 320, 971-975.

Ichino, A., \& Riphahn, R. T. (2005). The effect of employment protection on worker effort: absenteeism during and after probation. Journal of the European Economic Association, 3, 120143.

Layton, C. (1987). Levels of state anxiety for males facing redundancy and subsequent reporting to be employed or unemployed. Perceptual and Motor Skills, 65, 53-54.

Martikainen, P., Mäki, N., \& Jäntti, M. (2008). The effects of workplace downsizing on causespecific mortality: a register-based follow-up study of Finnish men and women remaining in employment. Journal of Epidemiology and Community Health, 62, 1008-1013.

Quinlan, M. (2007). Organisational restructuring/downsizing, OHS regulation andworker health and wellbeing. International Journal of Law and Psychiatry, 385-399.

Walde, K., \& Wei, P. (2007). International competition, downsizing and wage inequality. Journal of International Economics, 73, 396-406.

Wood, A. (1995). How trade hurt unskilled workers. Journal of Economic Perspectives, 9, 57-80. 